\title{
Abbreviations, Sources, and Translations
}

WORKS BY KANT CITED BY ABBREVIATION

A Anthropologie in pragmatischer Hinsicht (Kants gesammelte Schriften, vol. 7).

Anthropology from a Pragmatic Point of View. Trans. Mary J. Gregor. The Hague: Nijhoff, 1974.

CJ Kritik der Urteilskraft (KGS, vol. 5).

The Critique of Judgement. Trans. James Creed Meredith. Oxford: Oxford University Press, 1952.

E Pedagogie (KGS, vol. 9).

Education. Trans. Annette Churton. Ann Arbor: University of Michigan Press, 1960.

G Grundlegung zur Metaphysik der Sitten (KGS, vol. 4).

Groundwork of the Metaphysics of Morals. Trans. H. J. Paton. New York: Harper and Row, 1964.

L Logik (KGS, vol. 9).

Logic. Trans. Robert Hartman and Wolfgang Schwarz. Indianapolis: Bobbs-Merrill, I974.

LE Eine Vorlesung über Ethik. Hrg. Paul Menzer. Berlin: Rolf Heise, 1924. Lectures on Ethics. Trans. Louis Infield. Indianapolis: Hackett, I98 I.

MM Die Metaphysik der Sitten (KGS, vol. 6).

The Metaphysics of Morals. Trans. Mary J. Gregor. Cambridge: Cambridge University Press, 1991. I also utilize The Doctrine of Virtue: Part II of "The Metaphysics of Morals." Trans. Mary J. Gregor. New York: Harper and Row, 1964. Reprint, Philadelphia: University of Pennsylvania Press. 
PrR Kritik der praktischen Vernunft (KGS, vol. 5).

Critique of Practical Reason. Trans. Lewis White Beck. Indianapolis: Bobbs-Merrill, 1956.

$R \quad$ Die Religion innerbalb der Grenzen der blossen Vernunft (KGS, vol. 6). Religion within the Limits of Reason Alone. Trans. Theodore M. Greene and Hoyt H. Hudson. New York: Harper and Row, 1960.

V Metaphysik der Sitten Vigilantius. Vorlesungen, vol. 4. Vorlesungen über Moralphilosophie, zweite Hälfte, erster Teil (KGS, vol. 27).

\section{OTHER WORKS BY KANT CITED IN THE TEXT}

Beobachtungen über das Gefübl des Schönen und Erhabenen (KGS, vol. 2).

Observations on the Feeling of the Beautiful and Sublime. Trans. John T. Goldthwait. Berkeley: University of California Press, 1960.

"Das Ende Aller Dinge" (KGS, vol. 8).

"The End of All Things." In Perpetual Peace and Other Essays on Politics, History, and Morals, trans. Ted Humphrey. Indianapolis: Hackett, 1983.

"Mutmasslicher Anfang der Menschengeschichte" (KGS, vol. 8).

"Speculative Beginning of Human History." Trans. Ted Humphrey. In Perpetual Peace and Other Essays on Politics, History, and Morals, trans. Humphrey. Indianapolis: Hackett, 1983.

“On Philosophers' Medicine of the Body." Trans. Mary J. Gregor. In Kant's Latin Writings: Translations, Commentaries, and Notes, ed. Lewis White Beck in collaboration with Mary J. Gregor, Ralf Meerbote, and John A. Reuscher. New York: Peter Lang, 1986.

Praktische Philosophie Powalski. Vorlesungen, vol. 4. Vorlesungen über Moralphilosophie, erste Hälfte (KGS, vol. 27).

Vorlesungen über die philosophische Religionslehre. Hrg. Karl Heinrich Ludwig Pölitz. Leipzig, 1830.

Lectures on Philosophical Theology. Trans. Allen W. Wood and Gertrude M. Clark. Ithaca: Cornell University Press, 1978.

“Was Ist Erklärung?” (KGS, vol. 8).

"An Answer to the Question: What Is Enlightenment?" Trans. Ted Humphrey. In Perpetual Peace and Other Essays on Politics, History, and Morals, trans. Humphrey. Indianapolis: Hackett, 1983.

Apart from the Lectures on Ethics, Lectures on Philosophical Theology, and "On Philosophers' Medicine of the Body," all references to Kant are to Kants gesammelte Schriften (KGS), herausgegeben von der 
Deutschen (formerly Königlichen Preussischen) Akademie der Wissenschaften, 29 volumes (Berlin: Walter de Gruyter [and predecessors], 1902). References to the Lectures on Ethics are to the translation indicated of Eine Vorlesung über Ethik, edited by Paul Menzer (Berlin: Rolf Heise, 1924). I have also cited some sets of notes taken by Kant's students on his ethics lectures which are not included in Menzer's compilation: Praktische Philosophie Powalski and Metaphysik der Sitten Vigilantius. Both are in volume 4 of KGS.

References to "On Philosophers' Medicine of the Body" are to Kant's Latin Writings. "On Philosophers' Medicine of the Body" was published in $188 \mathrm{I}$ by Johannas Reicke, who found the manuscript among the papers of his father, Rudolf Reicke, archivist of Kant's Nachlass.

My citations of all works in KGS give the page number of the German text, and where the translations used do not provide the page number of the German text, I also provide the page number of the translation. I have in some instances altered the translations; in those instances, I indicate the alteration in a footnote. With some reluctance, I decided against substituting 'people' for 'men' as a translation of Menschen, even though 'people' is certainly more accurate. Mensch and Menschen, unlike 'man' and 'men', are clearly gender-neutral. To correct for this error was, I decided, too large an undertaking, for although Menschen translates more accurately as 'people' or 'humans' than as 'men', it would be misleading to suggest that Kant has both males and females in mind whenever he speaks of Menschen (where the context doesn't indicate otherwise). Sometimes he (apparently) does-and so I recoil when I quote the translation of "ich bin ein Mensch; alles, was Menschen widerfährt, das trifft auch mich" ( $\left.M M_{460}\right)$ as "I am a man; whatever befalls man concerns me too." (I do alter one such translation in Chap. 6; see n. 44.) But often he does not, and so it does not seem right to replace all translations of Mensch and Menschen with gender-neutral terms. Unsure how to resolve the problem, I generally deferred to the standard translations. 

KANTIAN ETHICS

ALMOST
WITHOUT
APOLOGY 
